\title{
NBSIR 73.177 \\ Comparison of the Fire Performance of Neoprene and Flame Retardant Polyurethane Mattresses
}

William J. Parker

Center for Building Technology

Institute for Applied Technology

National Bureau of Standards

Washington, D. C. 20234

April 1973

Final Report

Prepared for

Naval Ship Engineering Center

Hyattsville, Maryland 20782 


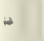

. 


\section{COMPARISON OF THE FIRE PERFORMANCE \\ OF NEOPRENE AND FLAME RETARDANT \\ POLYURETHANE MATTRESSES}

William J. Parker

Center for Building Technology

Institute for Applied Technology

National Bureau of Standards

Washington, D. C. 20234

April 1973

Final Report

This document has been prepared for the use of the Naval Ship Engineering Center. Responsibility for its further use rests with that agency. NBS requests that if release to the public is contemplated, such action be taken only after consultation with the Office of Public Affairs at the National Bureau of Standards.

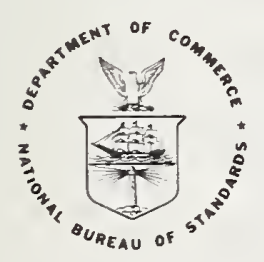

U. S. DEPARTMENT OF COMMERCE, Frederick B. Dent, Secretary 
Page

Abstract $\ldots \ldots \ldots \ldots \ldots \ldots \ldots \ldots \ldots \ldots \ldots \ldots \ldots \ldots \ldots \ldots \ldots \ldots \ldots \ldots$

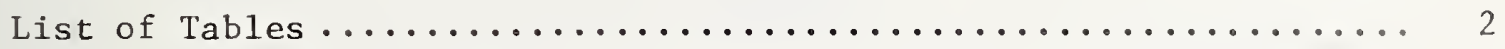

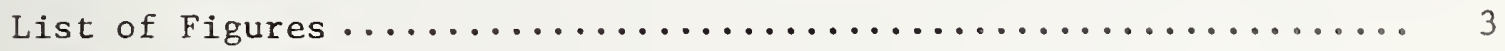

1.0 Introduction $\ldots \ldots \ldots \ldots \ldots \ldots \ldots \ldots \ldots \ldots \ldots \ldots \ldots \ldots \ldots$

2.0 Test Procedure $\ldots \ldots \ldots \ldots \ldots \ldots \ldots \ldots \ldots \ldots \ldots \ldots \ldots \ldots \ldots \ldots$

2.1 Full Scale Tests.......................... 5

2.1 .1 Description of the Test Specimens ............ 5

2.1 .2 Conduct of the Tests $\ldots \ldots \ldots \ldots \ldots \ldots \ldots \ldots \ldots$

2.2 Small Scale Laboratory Tests ................... 8

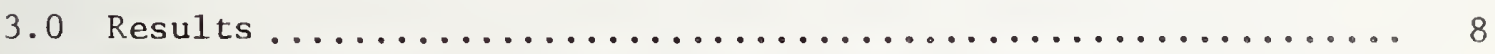

3.1 Observations on Fu11 Scale Tests ................ 8

3.1 .1 Condition $\|_{1} \ldots \ldots \ldots \ldots \ldots \ldots \ldots \ldots \ldots \ldots \ldots$

3.1 .2 Condition $\|^{2} \ldots \ldots \ldots \ldots \ldots \ldots \ldots \ldots \ldots \ldots \ldots \ldots \ldots \ldots \ldots \ldots$

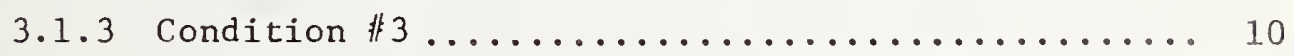

3.1 .4 Condition $\#^{4} \ldots \ldots \ldots \ldots \ldots \ldots \ldots \ldots \ldots \ldots \ldots \ldots \ldots$

3.2 Observations on Sma11 Scale Tests ................. 11

3.2 .1 Horizontal Tests ...................... 11

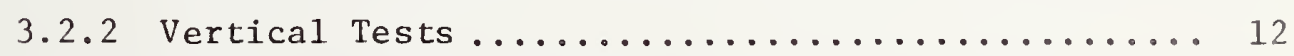

3.3 Measurements During Full Scale Tests ............... 13

3.4 East of Ignition ............................ 14

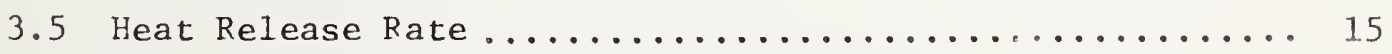

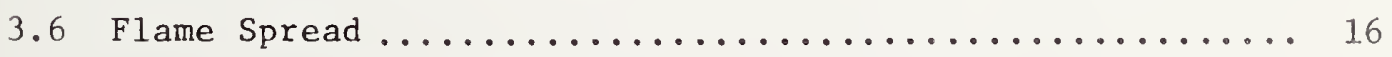

3.7 Smoke and Toxic Gases ...................... 16

4.0 Discussion $\ldots \ldots \ldots \ldots \ldots \ldots \ldots \ldots \ldots \ldots \ldots \ldots \ldots \ldots \ldots$ 


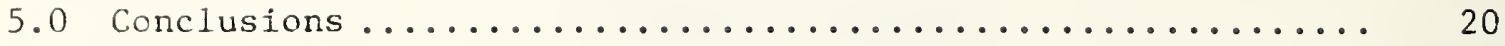

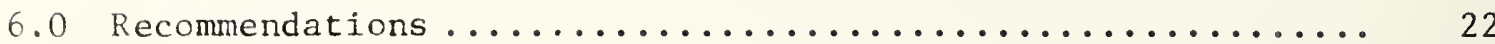

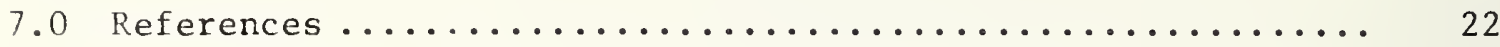

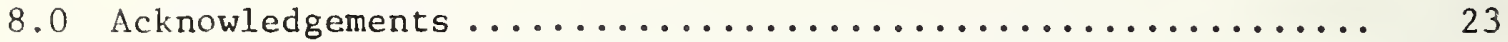


COMPARISON OF THE FIRE PERFORMANCE OF NEOPRENE

AND FLAME RETARDANT POLYURETHANE MAATTRESSES

\section{ABSTRACT}

Full scale fire tests of a neoprene and two different types of flame-retardant polyurethane mattresses were performed in a room sized compartment at the National Bureau of Standards. The mattresses were tested in two orientations, horizontal and vertical and with two types of coverings, a fire retardant treated cotton and a high temperature nylon ticking, in addition to the bare mattress insert. In addition to the visual observations, the burning rates, ceiling temperatures, optical density of the smoke, and the toxic gas concentrations were measured. This series of tests were repeated on small mattress sections to examine the relevance of small scale tests as a means of predicting full scale behavior. The flame spread index was measured with the radiant pane1 (ASTM E162); and the smoke and toxic gas concentrations were measured in the NBS smoke density chamber. Measurements were also performed in the heat release rate calorimeter and the ease of ignition test apparatus.

Key words: Fire test, ignition, heat release, toxic gases, mattress, fire retardant, smoke. 
I. Test Conditions

II. Maximum Gas Concentrations

III. Smoke, Weight Loss, and Temperature Data

IV. Measurements in NBS Smoke Density Chamber

V. Flame Spread and Heat Release 
1. Plan View of Test Roon!.

2. Fire Retarded Trested Cotton Covered Polyurethane $\#_{2}$ Mattress Being Tested in Condition 1 .

3. Polyurethane \#2 Mattress with High Temperature Nylon Cover Mounted in Frame For Test Condition $\#_{3}$.

4. Charred Fire Retarded Trested Cotton Cover on Polyurethane Mattress \#2 After Test Condition 1 .

5. Damage to Polyurethane \#2 Mattress After Test Condition \#1.

6. Polyurethane 非 1 Mattress Burning During Test Condition 非.

7. Polyurethane 非 2 Mattress Burning During Test Condition 非.

8. Burning of Polyurethane $\|_{2}$ Mattress in Test Condition 3.

9. Charred Fire Petardant Treated Cotton Cover on Neoprene Mattress Specimen After Horizontal Test in the Hood.

10. Bare Polyurethane 怙2 Mattress Specimen 20 Seconds After Ignition in the Horizontal Position in the Hood.

11. Bare Polyurethane 非 Mattress Specimen 7 Minutes After Ignition in the Horizontal Position in the Hood.

12. Vertical Test of a Polyurethane 非 Mattress Specimen Having a High Temperature Nylon Cover with Snaps at the Front End.

13. Flames Cccurring at Snapped End of High Temperature Nylon Cover on the Polyurethane 非 Mattress Specimen at 4 Minutes.

14. Total Involvement of the Polyurethane 非 2 Mattress Specimen Having the High Temperature lylon Cover with snapped End.

15. Empty Charred Nylon. Shell Near the End of the Test of the Polyurethane \#2 Mattress Specimen with the Snapped End. 


\subsection{INTRODUCTION}

Burning mattresses may generate large quantities of heat which could contribute to the severity of any fires in which they are involved. Further, if large quantities of smoke and toxic gases are released during the burning of the mattresses, these may circulate to other areas and cause a potentially serious life hazard. In addition, the reduction in visibility caused by the smoke interferes both with efforts to escape the hazardous areas and with efforts to suppress the fire. This is a particularly serious problem aboard ship. A project to evaluate several aspects of the fire performance of burning mattresses was undertaken at the National Bureau of Standards under sponsorship of the Naval Ship Engineering Center.

Although the mattresses are horizontal in use they may be oriented vertically in storage. Since the potential fire hazard may be quite different for the two cases, tests were performed in both orientations.

In order to compare the ignitability, heat release rate, and the smoke and toxic gas generation for the various types of mattresses and covers being considered for use by the Navy, twelve fire tests on fullsized mattresses were conducted in a 100-sq. ft. room in the NBS fire laboratory. Six mattress and ticking combinations were tested in a vertical, well ventilated condition, and six in a horizontal, poorly ventilated condition. 
In addition, small scale laboratory tests were conducted to measure the degree of correlation between small and full scale tests and thus provide a potential basis for future material specifications. Comparisons were made of the heat release rate and the smoke and toxic gas production for each of the mattress and cover combinations with the heat release calorimater ${ }^{1}$ and the smoke density chamber ${ }^{2}$. Ignition and flame spread data were also obtained with the ease of ignition test ${ }^{3}$ and the ASTM, E162 radiant pane1. 4

A11 of the mattresses tested on this project have passed the cigarette ignition test of the mattress flammability standard ${ }^{5}$ DOC-FF4-72. On the other hand they would all be consumed in the event of a severe fire exposure. An intermediate exposure level was used in these tests to show the greatest differences in response to fire among the mattresses and cover combinations. Currently, mattresses and tickings are required to meet the flammability criteria in the military specifications, MIL-M-18351 and CCC-C-436 respective1y.

\subsection{TEST PROCEDURE}

\subsection{Full Scale Tests}

\subsubsection{Description of Test Specimens}

The mattresses included neoprene and two different types of flameretardant polyurethanes, labelled 非 1 and $\#_{2}$ in this report. The numbers relate to the order in which they were tested. The mattresses were tested bare, and with two types of ticking, flame retardant treated cotton (FR cotton) and high temperature nylon (HT nylon). The mattresses were 76 inches long, 26 inches wide and 3 inches thick. 


\subsubsection{Conduct of Tests}

Full scale fire tests of the mattresses from three manufacturers were run on successive days. On each day the mattresses of a single manufacturer were burned under the four different test conditions listed in Table $I$.

In condition 1 the mattress had a fire retardant treated cotton (FR cotton) cover and was located in the horizontal position with the room ceiling vent closed.

In condition 2 the mattress had no cover and was also located in the horizontal position with the ceiling vent closed.

In condition 3 the mattress had a high-temperature nylon (HT nylon) cover and was located in a vertical position with the ceiling vent open and the exhaust fan operating.

Condition 4 was the same as condition 3 except that a FR cotton ticking was used instead of the HT nylon.

Under normal cool air conditions the exhaust fan draws 1500 CFM of air through the $14-1 / 2 \times 15$ inch ceiling vent. The $34 \times 80$ inch door into the room where the mattresses were burned was open for all of the tests. The floor of the room was 9 feet, 7 inches wide, and 10 feet, 5 inches long with a ceiling height of 8 feet. The floor plan is shown in Figure 1.

The mattresses were burned on a platform supported by load cells to provide a continuous measure of the burning rate during the test. For the horizontal condition they were centered on an asbestos cement board support 84 inches long and 34 inches wide. A mattress being tested in 
condition 1 is shown in Figure 2. The vertical specimens were mounted in an angle iron support frame as shown in Figure 3.

In the horizontal position the fire was started by igniting $50 \mathrm{ml}$ of ethanol placed on the center of the top surface of the mattress. In the vertical orientation the fire was started by igniting $500 \mathrm{ml}$ of ethanol in a steel pan 80 inches long, 3-1/4 inches wide, 2 inches deep, and located 1 inch below the mattress. Without the mattress in place the alcohol burned for 3 minutes. In the presence of the mattress the alcohol flames persisted for as long as 5 minutes.

The quantities of ethanol specified in this procedure were determined by preliminary tests aimed at finding an intermediate exposure level which would provide the maximum distinction between the fire performances of the mattresses.

The concentrations of the toxic gases; CO (carbon monoxide), HCl (hydrogen chloride), HCN (hydrogen cyanide) and the oxides of nitrogen; were measured with colorometric detector tubes at a point 4 inches down from the ceiling and 8 inches from the center of the rear wall of the room. A thermocouple was located on the ceiling directly above the mattress to obtain a relative measure of the rate of heat production. The optical density of the smoke was measured over a horizontal light path 10 feet, 5 inches long located 5 feet, 2 inches above the floor and 13 inches from the wall farthest from the mattress. See Figure 1 . A tungsten filament lamp and a collimating lens were used to produce the light beam. A phototube with an S-4 cathode surface was used to measure the transmitted light. 


\subsection{Small Scale Laboratory Tests}

All of the full scale tests were modeled by burning $8-1 / 2$ inch $x$ 8-1/2 inch sections of the mattress and ticking combinations in a standard chemical hood. Motion picture and slide coverage was provided for these small scale tests as well as for those run at full scale.

As in the full scale tests, the horizontal tests in the hood used $50 \mathrm{ml}$ of ethanol on the upper surface for ignition. The vertical tests in the hood utilized $50 \mathrm{ml}$ of ethanol which provided the same depth of fuel in the pan below the mattress as was provided in the full scale test. Consequently the burning times of the alcohol were approximately the same for the small and full scale tests.

The radiant panel $1^{4}$ and the smoke density tests ${ }^{2}$ were run on $3 / 4$ inch thick specimens for all the mattress and cover combinations. Both flaming and non-flaming modes were used in the smoke density test, and the toxic gas concentrations were measured at the same time.

In order to hande the melting specimens in the ease of ignition test $^{3}$ an insert was provided in the holder to catch the melting material and permit it to burn in contact with the lower edge of the specimen. The heat release rate calorimeter ${ }^{1}$ specimens were burned in a pan attached to the front of the holder. The heat of the combustion was also measured with the oxygen bomb calorimeter for each of the mattress and ticking materials.

\subsection{RESULTS}

\subsection{Observations on the Full Scale Tests}

\subsubsection{Condition 1}

The FR cotton covers prevented complete fire involvement in any of 
the mattresses tested in the horizontal position. Some melting and pyrolyzing of both polyurethanes occurred to a depth of less than 1 inch directly under the area in which the ethanol was burned. Flames appeared to persist only as long as the alcohol was present. The FR cotton cover was charred over the burning area which was approximately 6 inches in diameter. This char layer prevented the direct exposure of the mattress to the flame. The charred cover is shown in Figure 4 and the damage to the polyurethane underneath is seen in Figure 5.

A thin hard crust was formed on the neoprene mattress surface directly below the charred area of the FR cotton cover. Underneath the crust the neoprene appeared to be unaffected.

\subsubsection{Condition 2}

The differences in the fire behavior among the mattresses was more pronounced without the covers. The neoprene mattress again formed a thin crust over the area under the ethanol spill with no damage beneath.

The polyurethane \#1 mattress continued to burn in the area of the ethanol spill until the full thickness of the mattress was burned through. The coupling between the flame and the uncovered mattress was sufficient to maintain the melting and pyrolyzing of the polyurethane until the bottom of the mattress was reached. However, there was no tendency for the fire to spread beyond the original area. The burning of this mattress is shown in Figure 6.

The polyurethane $\# 2$ mattress burned down through the complete thickness and then the fire spread laterally until the whole mattress was consumed. The burning of this mattress is shown in Figure 7. The polyurethane $\# 2$ mattress seemed to melt more readily and the liquid 
produced was more flammable than that of the polyurethane 非 1 mattress. The feeding of the flame by the melted material flowing into the flame zone caused the lateral spread of fire along the polyurethane 非 2 mattress.

\subsubsection{Condition 3}

In the vertical position the polyurethane mattresses 1 and 2 started to burn at the ends where the ticking had snap fastenings so that some of the mattress was exposed at the top and bottom corners. Openings at these corners provided a source of air at the bottom and an exhaust vent at the top. Fire started at the snapped end and progressed into the mattress with flaming combustion inside of the HT nylon cover. The progress was slow in the polyurethane 非 1 mattress and about 24 percent of it was consumed by the time the fire went out in twelve minutes. In a second full scale test of this mattress, with the snapped end reversed, it appeared to be burning to completion but very slowly. The polyurethane \#2 mattress was 90 percent consumed in 24 minutes inside of the HT nylon cover, which was charred and deformed. The fire was put out at this time because it was apparent it would burn to completion. The burning of the polyurethane $\$ 2$ mattress is seen in Figure 8 . The role of the opening at one end of the ticking was quite important to ignition and fire propogation in these two cases.

For the neoprene, smoldering combustion started at the end away from the snaps and progressed very slowly along the mattress. At 35 minutes, after $1 / 3$ of the mattress had been consumed it was apparent that the smoldering would eventually consume the whole mattress so the test was stopped. 


\section{1 .4 Condition 4}

The polyurethane $\#_{1} 1$ mattress with the FR cotton cover started to burn at the snapped end and the fire propagated slowly along the length as it did with the HT nylon cover. When the test was stopped at 35 minutes the mattress was almost completely consumed but the upper part of the FR cotton cover at the far end was only slightly affected. The flames broke through the bottom of the cover allowing the melted polyurethane to drip and burn in the pan beneath the mattress.

The polyurethane $\#_{2}$ mattress flamed strongly at one minute, at the end of the mattress away from the snaps. The mattress was essentially consumed in 13 minutes, except for some remaining liquid polyurethane which was burning in the pan when the fire was extinguished at 16 minutes

For the neoprene mattress the filames were out in $6-1 / 2$ minutes. Smoldering continued until it was apparent that the whole mattress would be destroyed. The test was stopped in 35 minutes with about one third of the mattress consumed.

\subsection{Observations During Small Scale Tests}

The results of the horizontal tests in the hood with the $8-1 / 2 \mathrm{x}$ $8-1 / 2$ x 3 inch specimens qualitatively duplicated those of the full scale tests.

\subsubsection{Horizontal Tests}

The polyurethane mattress specimens covered with FR cotton burned as long as the alcohol lasted which was about 5 minutes and then went out with a small amount of melting and loss of material just below the charred cotton cover. The flames were out on the neoprene specimen in 
about 2-1/2 minutes, with some crusting of the surface below the cover. The charred cotton cover is seen in Figure 9.

In the case of the bare horizontal mattress the neoprene specimen stopped flaming at 4-1/4 minutes when the alcohol near the surface burned out. Much of the alcohol seeped through to the bottom of the mattress as it did in the full scale test, due to the porosity of the neoprene.

The bare polyurethane \#1 specimen burned through the complete thickness of the mattress in the region of the alcohol spill, but the fire did not spread to the edge of the specimen. The flames were out in 8 minutes.

The bare polyurethane \#2 specimen is shown in Figure 10 twenty secords after ignition. It burned through to the bottom in $4-1 / 4 \mathrm{minutes}$. The burning zone reached the edge of the specimen in 5 minutes. Al1 of the solid was melted or consumed within 6 minutes and the flaming ceased with the complete consumption of the sample, except for some residual char, in 12 minutes. The burning of the pool of polyurethane at 7 minutes is seen in Figure 11 .

\subsubsection{Vertical Tests}

The findings of the vertical tests of the small scale $8-1 / 2 \times 8-1 / 2$ $x 3$ inch specimens in the hood were also in agreement with those of the full scale tests. The flames went out in $3-1 / 4$ and $4-1 / 2$ minutes, respectively, for the polyurethane $\|_{1}$ and $\# 2$ mattress specimens with the HT nylon covers without a snapped end. There was only a 15 percent weight loss in the first case and 12 percent in the second one.

The vertical tests were repeated with one snapped end, so that the upper and lotier corners of one edge of the specimen were exposed as they werc in the full scale tests. The snapped end is seen in Figure 12 for 
the polyurethane $\# 2$ specimen and the flaming from the upper corner is seen in Figure 13 followed by complete involvement in Figure 14. This specimen burned to completion in 35 minutes inside of the HT nylon cover which remained as an empty charred shell as seen in Figure 15. The polyurethane 非 specimen did not burn to completion. The comparison between the two types of mattresses and the role of the snapped end seems to be adequately demonstrated by the small scale tests.

The vertical neoprene mattress specimens were completely consumed by smoldering in the hood for one hour both with the HT nylon and the FR cotton covers, again duplicating the behavior of the full scale tests. The neoprene mattress specimens in the hood did not have snapped ends but the full scale tests did not indicate that the edge exposure was important for these mattresses which burned in a smoldering mode.

The FR cotton covered polyurethane 非 and 非 2 specimens were completely consumed ins6de of their charred FR cotton shells in $12-1 / 4$ and 10 minutes respectively. These covers did not have snaps.

\subsection{Measurements During Full Scale Tests}

The maximum concentrations of the toxic gases in the room during the full scale tests are recorded in Table II. The absolute concentrations are difficult to interpret but the comparison between mattress types for a particular test condition is meaningful. For the active burning conditions 3 and 4 , the $\mathrm{HCl}$ levels of the neoprene were definitely higher than for the polyurethanes The low values of Hcl for neoprene in conditions 1 and 2 are a result of the very small amount of burning that took place. The other toxic gases are more dominant for the treated polyurethones. The polyurethane 1 mattress which did not burn as 
vigorously as the polyurethane $\#_{2} 2$ mattress produced more $\mathrm{CO}$ in conditions 3 and 4. These findings are reasonable in light of the chemical composition of the different materials.

The maximum optical density (absorbance) of the smoke per foot, the burning rate, total weight loss, burning time, and the maximum ceiling temperature are tabulated in Table III. The highest smoke densities were obtained for the polyurethane mattresses where the light level became too low to measure for an extended period of time for polyurethane 非 in condition 4 and polyurethane $\$ 2$ during condition 2 . The sensitivity of the measurement was such that the smallest transmission that could be measured was 0.001 which corresponds to a maximum optical density per foot of 0.3 .

The maximum burning rate was highest for the polyurethane 非 mattresses and lowest for the neoprene. For the horizontal tests the specimen burned until a constant weight loss was achieved. The vertical tests which were extended much further in time were cut off when it was apparent that a complete burnout would occur. The exception was the polyurethane 非 I mattress in condition 3 which went out in 12 minutes. The test was repeated with the snapped end of the mattress reversed. In this case, the snapped end near the door, 60 percent of the mattress was consumed by the time the test was stopped at 35 minutes. The higher ceiling temperatures observed above the polyurethane $\#_{2}$ mattresses reflect the higher burnirg rates.

\subsection{Ease of Ignition}

By providing a container at the base of the specimen to catch the melted material in the ease of ignition test apparatus, ignition was 
sustained in the polyurethane $\# 2$ mattress specimen after a 70 second exposure, when the thickness was 1-1/2 inches. For smaller thicknesses of the polyurethane $\# 2$ specimens and for all thicknesses of the polyurethane 非 1 specimens, including the full thickness of the 3 inch mattress, the specimen melted completely without sustaining a flame. This included exposure times up to 7 minutes. The neoprene mattress did not flame at any thickness, but after a 105 second exposure a 3 inch thick specimen continued to smolder until it was completely consumed, except for a thin hard crust formed on all surfaces of the specimen. These tests showed the polyurethane 2 mattress to be the most easily

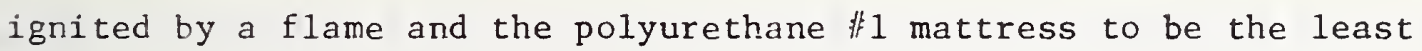
readily ignitable. This is contrary to the full scale tests and the tests in the hood in which the polyurethane 1 I would ignite in a horizontal location but the neoprene would not, even in a smoldering mode. Thus the ease of ignition test did not provide correlatable information on the ignitability of mattresses.

\subsection{Heat Release Rate}

The heat release rates given in the Table IV are based on the average of 3 determinations. The greatest differences in heat release rate occur for the bare matress where the rates for the polyurethanes are much higher than for the neoprene. The cover tends to minimize the difference by impeding the heat flow into the mattress and reducing the heat released. The incident heat flux of $6 \mathrm{~W} / \mathrm{cm}^{2}$ used in the test would be produced by a fairly intense fire in a compartment in which case all of the mattresses would burn fairly rapidly. The densities and heats of combustion of the pads and tickings are also listed in Table IV. 


\subsection{Flame Spread}

Specimens 6 inches wide, 18 inches long, and $3 / 4$ inches thick of the three different types of mattresses were measured with the radiant panel in accordance with the ASTM E162 procedure. The specimens were either bare or covered with FR cotton or HT nylon ticking and were restrained in the holder with 1 inch mesh chicken wire. Specimens of the two types of ticking were also tested separately.

The flame spread ratings given in Table IV reflect the difference in burning behavior of the full size mattresses. The highest flame spread was for the polyurethane $\sum^{2}$ and the lowest was for the neoprene. The flame spread number indicates that HT nylon is a better ticking than FR cotton for the polyurethane, but not as good for the neoprene.

\subsection{Smoke and Toxic Gases}

The optical density of the smoke and the concentrations of HCN, HC1, CO, and the oxides of nitrogen were measured for both the smoldering and flaming modes of combustion in the NBS smoke chamber for all of the mattress and cover combinations and the mattresses and covers by themselves. These are recorded in Table $V$. There is an exceptionally low optical density for the flaming mode for polyurethane 非. Since the flaming areas on the polyurethanes were nearly always accompanied by smoldering regions in the full scale tests the significance of this low value is not too important. Although the polyurethanes had someshat lower smoke density values for the smoldering mode they had significantly greater areas of involvement in the full scale tests due to their greater flammability. Thus it is difficult to make predictions regarding the 
smoke producti4n levels for the full sicale tests where the area of involvement Is qulte unpredfetable. I'owever, the total amount of amoke produced should be comparable with the smoke densities measured in the smoke density chamber. The smoke measurement in the room is more a measurement of the rate of production than a measurement of the total smoke produced. The smoke chamber measures the total smoke produced. The indicated toxic gas concentrations are similar except for the $\mathrm{HCl}$ which are an order of magnitude higher for the neoprene.

\subsection{DISCUSSION}

The objectives of this series of tests were: (1) to provide experimental evaluations on the full scale fire performance of three particular mattresses and two particular tickings of interest to the Navy, (2) to provide small scale laboratory data suitable for judging the performance of the mattress combinations in fire situations, and (3) to compare the results of the small scale and full scale tests in order to assess the need for the latter in the future. To begin with these pads and tickings were chosen because of their assumed low fire risk. They would all easily pass the mattress flammability standard. 5 on the other hand they would all contribute significantly to the severity of a fully developed fire. It was necessary to pick some realistic intermediate set of conditions wherein the differences between them would become apparent. One fully instrumented test was run on each combination and orientation. Because borderline exposure conditions were chosen to amplify the differences in performance, one could expect a certain amount of variability between tests. This could not be observed without running several replications of each test. On the other hand the number of tests which 
would be required to make a high degree of statistical correlation would have been prohibitive on a small project. Due to the lack of repetition the numerical results of the full scale tests described in this report should be considered to be approximate. llowever, the qualitative differences in the burning behavior of these mattresses does seem to be adequately established and to be consistent with the small scale tests and the standard laboratory tests.

The performance of the neoprene mattress was superior to that of the two polyurethanes in the full scale tests, based on the burning rate, heat release rate, and damage to the mattress. This was in agreement with the results of the small scale tests, the radiant panel test, and the heat release rate calorimeter.

The neoprene mattress was slightly better than the polyurethanes in terms of observed smoke levels in the room. This finding was not in agreement with the smoke density chamber which rates the polyurethanes somewhat better than the neoprene. The principal reason for this difference is that the smoke density chamber retains all of the smoke that is produced and the reported maximum optical density does not depend on the rate of production. In the large scale tests smoke was continually removed through the door and through the vent in the case of the vertical tests so that the observed smoke level depended on the rate of production. Because of the lower burning rate of the neoprene its rate of smoke production was less. The unpredictable area of involvement of the mattresses and the burning of the material inside of the cover under a reduced oxygen concentration were other complicating factors. 
The results of the tests indicate that the radiant panel would be ideally suited to bringing out the differences in burning behavior of the mattresses. Bare neoprene and neoprene with each of the covers had flame spread ratings of less than 25 measured with the E162 test whereas the bare and covered polyurethanes all had flame spread ratings in excess of 25 by the same test.

The smoke density chamber could give a maximum potential of smoke level resulting in a closed room, but does not give an adequate indication of the smoke level that would result from a mattress fire in a room where either forced ventilation or free circulation through a doorway is involved.

Although the burning rates and smoke levels were not measured in the small scale tests, the qualitative agreement in the observed burning behavior with the full scale tests suggest the possible development of a small scale test in which the mattress specimens are burned on a weight loss platform in a ventilated chamber with a smoke meter installed inside. In this way both smoke production and burning behavior could be evaluated in the same chamber under realistic conditions.

The optical densities per foot (D/l) in the full scale tests are several orders of magnitude less than the specific optical densities $\left(D_{S}\right)$ measured in the NBS smoke chamber. The reason for this can be illustrated for the case of the vertical test on the neoprene with the HT nylon cover. $D_{S}$ was measured to be 325 on a specimen $3 / 4$ in. thick. For the 3 in. mattress it should be 1300 . If all of the smoke had been contained in the measurement room the $\mathrm{D} / \ell$ would be given by $D / R=(A / V) D_{S}=22.3$ per foot where $A$ is the area of one side of the 
mattress and $V$ is the volume of the room. Forty percent of the mattress was consumed in 35 minutes. The air was removed through the exhaust vent at the rate of 1500 cubic feet per minute. This would result in 66 room air changes during the burning period. The above value of $\mathrm{D} / \ell$ should be multiplied by the fraction of the mattress consumed and divided by the number of air changes. This yields an average value of 0.13 per foot. This is an order of magnitude calculation. The smoke carried out through the doorway would reduce this number somewhat farther. The measured maximum was 0.15 per foot. The closeness of these numbers indicates that the smoke chamber can give an order of magnitude approximation of the smoke level.

The same calculation on the vertically tested FR cotton covered neoprene would yield a value of about 0.2 and the peak measured value was about 0.1 .

\subsection{CONCLUSIONS}

The following conclusions are drawn from the results of the full scale tests, the small scale testsc and the standard laboratory tests. They refer to the three mattress types tested on this project.

(1) Small level fires, as simulated by the lighted alcohol spill on the top surface, are not sufficient to ignite a horizontal mattress if it is protected with a fire retardant treated cotton or high temperature nylon ticking. A neoprene mattress will not ignite under these conditions, even without a cover.

(2) If the fire exposure is intense enough all of the mattress and cover combinations will burn. 
(3) For intermediate level fire exposures the polyurethane \#2 burns much more rapidly than the other two mattresses. The neoprene mattress burns the slowest of the three and the burning is confined to the smoldering mode.

(4) The smoke concentrations (optical densities) produced were similar among the polyurethane mattresses but lower for the neoprene.

(5) The concentration of $\mathrm{HCl}$ was highest for the neoprene while the concentration of the other toxic gases were somewhat higher for the polyurethanes.

(6) The qualitative behavior of the full scale mattress burns can be predicted from small scale tests with $8-1 / 2 \times 8-1 / 2 \times 3$ inch specimens.

(7) The burning rates were highest for the mattresses with the highest flame spread ratings obtained with the radiant panel and with the highest heat release rates obtained with the heat release rate calorimeter.

(8) The exposure of the pad near the snapped end of the mattress cover increases considerably its vulnerability to fire.

(9) The fire retardant treated cotton ticking provides considerable protection to the polyurethanes; and the high temperature nylon provides even more. However, the presence or absence of a ticking makes very little difference to the fire hehavior of a neoprene mattress. 
(10) In overall rating of fire hazard the neoprene mattress would appear to present the least contribution to the fire hazard under an intermediate leve1 fire.

\subsection{RECOMMENDATIONS}

It is recommended that

(1) The E162 radiant panel test should be used to rank mattresses in regard to their burning behavior.

(2) A small scale test should be developed to measure the rate of smoke production of different mattress materials in order to compare the smoke levels which would be achieved in a controlled ventilation compartment involved in a mattress fire. The small size matress specimens should be burned in the manner specified in this report so that the smoke production rate properly reflects the burning behavior of the mattresses in a real fire.

(3) The NBS smoke density chamber can be used as a measure of the total smoke produced and could be used to estimate the smoke distribution in the air handling system.

\subsection{REFERENCES}

1. W. J. Parker and M. E. Long, "Development of a Heat Release Rate Calorimeter at NBS," Ignition, Heat Release, and Noncombustibility of Materials, ASTM STP 502, American Society of Testing and Materials, 1972 , pp. 135-151. 
2. D. Gross, J. J. Loftus, and A. F. Robertson, "Method for Measuring Smoke from Burning Materials," ASTM Special Technical Publication No. 422 (1967).

3. W. J. Parker, "The Development of a Test for Ease of Ignition by Flame Impingement - Progress Report," September 3, 1971.

4. ASTM E162-67, "Surface Flammability of Materials Using a Radiant Heat Energy Source," ASTM Book of Standards, Part 14, page 558, (1972).

5. "Flammability Standard for Mattresses, DOC FF 4-72", Federal Register, Volume 37, Number 110, June 7, 1972, pages 11362-11367.

\subsection{ACKNOWLEDGEMENT}

I am endebted to Jim Conway of the Philadelphia Naval Shipyard Code 134.1 for his helpful suggestions and observations during the development and running of these tests.

I also appreciate the contribution made to the project by all of the technicians in the Building Fires and Safety Section. 

TABLE I TEST CONDITIONS

\begin{tabular}{|c|c|c|c|c|}
\hline $\begin{array}{c}\text { Test } \\
\text { Condition }\end{array}$ & Ticking & Orientation & $\begin{array}{l}\text { Room } \\
\text { Vent }\end{array}$ & Fan \\
\hline 1 & $\begin{array}{l}\text { Fire retardant } \\
\text { treated cotton }\end{array}$ & horizontal & closed & off \\
\hline 2 & none & horizontal & closed & off \\
\hline 3 & $\begin{array}{c}\text { High temperature } \\
\text { nylon }\end{array}$ & vertical & open & on \\
\hline 4 & $\begin{array}{l}\text { Fire retardant } \\
\text { treated cotton }\end{array}$ & vertical & open & on \\
\hline
\end{tabular}


TABLE II MAXIMUM GAS CONCENTRATIONS

\begin{tabular}{|c|c|c|c|c|}
\hline Test & $\mathrm{CO}$ & HCl & $\mathrm{HCN}$ & $\mathrm{NO}+\mathrm{NO}_{2}$ \\
\hline U1 & --- & --- & -- & -- \\
\hline $\mathrm{T} 1$ & -- & 10 & --- & $-\cdots$ \\
\hline S1 & --- & 10 & 10 & 1.5 \\
\hline $\mathrm{U} 2$ & 250 & 10 & $\cdots$ & 3 \\
\hline $\mathrm{T} 2$ & --- & 0 & --- & -- \\
\hline S2 & 100 & 90 & 5 & 5 \\
\hline U3 & 750 & 35 & 25 & 8 \\
\hline $\mathrm{T} 3$ & 150 & $>100$ & 2.5 & 2 \\
\hline S3 & 300 & 40 & 5 & 20 \\
\hline U4 & 750 & 55 & 25 & 5 \\
\hline T4 & 100 & $>100$ & 5 & Trace \\
\hline S4 & 300 & $>0$ & 10 & 30 \\
\hline
\end{tabular}

U refers to Polyurethane 非

$\mathrm{T}$ refers to Neoprene

$\mathrm{S}$ refers to Folyurethane $\# 2$ 
TABLE III SMOKE, WEIGHT LOSS, AND TEMPERATURE

DATA IN FULL SCALE TESTS

\begin{tabular}{|c|c|c|c|c|c|}
\hline Test & $\begin{array}{l}\text { Maximum } \\
\text { Optical } \\
\text { Density } \\
\text { of Smoke } \\
\text { (per foot) }\end{array}$ & $\begin{array}{c}\text { Maximun } \\
\text { Burning } \\
\text { Rate } \\
\text { (lbs/min) }\end{array}$ & $\begin{array}{l}\text { Total } \\
\text { Weight } \\
\text { Loss } \\
(\%)\end{array}$ & $\begin{array}{c}\text { Burning } \\
\text { Time } \\
\text { (Min) }\end{array}$ & $\begin{array}{c}\text { Maximum } \\
\text { Ceiling } \\
\text { Temperature } \\
\left({ }^{\circ} \mathrm{C}\right)\end{array}$ \\
\hline U1 & 0.003 & $-\cdots$ & 2.1 & 5 & 41 \\
\hline $\mathrm{T} 1$ & 0.002 & --- & 1.1 & 2.3 & 31 \\
\hline S1 & 0.001 & --- & 1.5 & 5 & 31 \\
\hline U2 & 0.07 & --- & 11 & 8 & 34 \\
\hline $\mathrm{T} 2$ & 0.0005 & --- & 0.9 & 1.8 & 20 \\
\hline S2 & $>0.3$ & 3.5 & 100 & 23 & 402 \\
\hline U3 & 0.09 & 0.42 & 24 & 12 & 60 \\
\hline U3' & & & 60 & $35 *$ & \\
\hline T3 & 0.15 & 0.19 & 40 & $35 *$ & 81 \\
\hline S3 & 0.09 & 1.0 & 90 & $24 *$ & 188 \\
\hline U4 & $>0.3$ & 0.31 & 81 & $32 *$ & 62 \\
\hline $\mathrm{T} 4$ & 0.09 & 0.23 & 42 & $35 *$ & 71 \\
\hline S4 & 0.14 & 3.5 & 97 & $16 *$ & 190 \\
\hline
\end{tabular}

U refers to Polyurethane $\equiv_{1}$.

$T$ refers to Neoprene.

$S$ refers to Polyurethane $\#^{2}$.

U3' was an uninstrumented repeat of U3 with the snapped end reversed.

* Fire was stopped at this time when it appeared obvious that the mattress would continue to burn to completion. 
TABI,E IV FIAAME SPRFAD AND HFAT REI.EASE

\begin{tabular}{|c|c|c|c|c|c|}
\hline Pad & Ticking & $\begin{array}{l}\text { F1 ame } \\
\text { Spread } \\
\text { (E162) }\end{array}$ & $\begin{array}{l}\text { Heat } \\
\text { Release } \\
\text { Rate } \\
\left(\mathrm{W} / \mathrm{cm}^{2}\right)\end{array}$ & $\begin{array}{l}\text { lleat of } \\
\text { Combustion } \\
(\text { BTV/1b) }\end{array}$ & $\begin{array}{l}\text { Malcerlul } \\
\text { Density }\end{array}$ \\
\hline Neoprene & None & 4 & 6.5 & 10,140 & $3.7 \mathrm{Ibs} / \mathrm{ft}^{3}$ \\
\hline Neoprene & FR Cotton & 4 & 14 & & \\
\hline Neoprene & HT Nylon & 22 & 5.4 & & \\
\hline $\begin{array}{l}\text { Polyurethane } \\
\text { 非 }\end{array}$ & None & 140 & 18 & 9,130 & $3.2 \mathrm{Ibs} / \mathrm{ft}^{3}$ \\
\hline $\begin{array}{l}\text { Polyurethane } \\
\text { \#1 }\end{array}$ & FR Cotton & 242 & 11 & & \\
\hline $\begin{array}{l}\text { Polyurethane } \\
\text { \#1 } 1\end{array}$ & HT Nylon & 65 & 8.0 & & \\
\hline $\begin{array}{l}\text { Polyurethane } \\
\quad \# 2\end{array}$ & None & 477 & 22 & 10,700 & $3.51 \mathrm{bs} / \mathrm{ft}^{3}$ \\
\hline $\begin{array}{l}\text { Polyurethane } \\
\quad \text { ⿰⿰三丨⿰丨三⿻2 }\end{array}$ & FR Cotton & 515 & 14 & & \\
\hline $\begin{array}{l}\text { Polyurethane } \\
\quad \# 2\end{array}$ & HT Nylon & 186 & 9.7 & & \\
\hline None & FR Cotton & 2 & --- & 7,090 & $7.2 \mathrm{oz} / \mathrm{yd}^{2}$ \\
\hline None & HT Nylon & 1 & --- & 11,400 & $5.7 \mathrm{oz} / \mathrm{yd}^{2}$ \\
\hline
\end{tabular}


TARLE V MEASLREMENTS I $N$ NES SMOKE DENSITI CHAMER

Mattress

Pad
Cover

FR Cotton

HT Nylon

325

Polyurethane 非

Polyurethane 非1

Polyurethane 非 1

Polyurethane 非 2

Polyurethane 非2

Polyurethane \#12.

None

472

240

FR Cotton

432

248

HT Nylon

477

176

None

295

FR Cotton

419

288

HT Nylon

331

262

None

FR Cotton

None
Mode

F-flaming

S-smoldering
Gas Concentration (ppm) HCN $\mathrm{HCl} \quad \mathrm{CO} \quad \mathrm{NO}_{2} \mathrm{NO}_{2}$

$\begin{array}{rrrrr}\mathrm{F} & 10 & 700 & 1000 & 13 \\ \mathrm{~S} & 8 & 200 & 500 & 2\end{array}$

$\begin{array}{lllll}\text { F } & 25 & 1000 & 1200 \quad 7\end{array}$

$\begin{array}{lllll}\mathrm{S} & 25 & 350 & 1000 & 1\end{array}$

HT Nylon
379

50

\section{F}

$\mathrm{S}$

F

S

F

$\mathrm{S}$

F

S

F

$\mathrm{S}$

41

42

19

6

25

2

$\begin{array}{rrrr}25 & 600 & 700 & 12\end{array}$

$\begin{array}{llll}50 & 75 & 1500 & 15\end{array}$

$\begin{array}{llll}2 & 35 & 125 & 1\end{array}$

25

12

$45 \quad 750$

$40 \quad 400$

$\begin{array}{llll}65 & 80 & 2500 & 10\end{array}$

$\begin{array}{llll}2 & 25 & 125 & 1\end{array}$

$\begin{array}{llll}25 & 30 & 500 & 40\end{array}$

$\begin{array}{llll}5 & 4 & 200 & 3\end{array}$

F

$S$

F

S
25

12

25

10

10

5

20
$40 \quad 1000 \quad 30$

$\begin{array}{lll}12 & 750 & 12\end{array}$

$25 \quad 1000 \quad 40$

F

F

$\mathrm{S}$

$\begin{array}{rrr}2 & 500 & 15 \\ 4 & 20 & 1\end{array}$





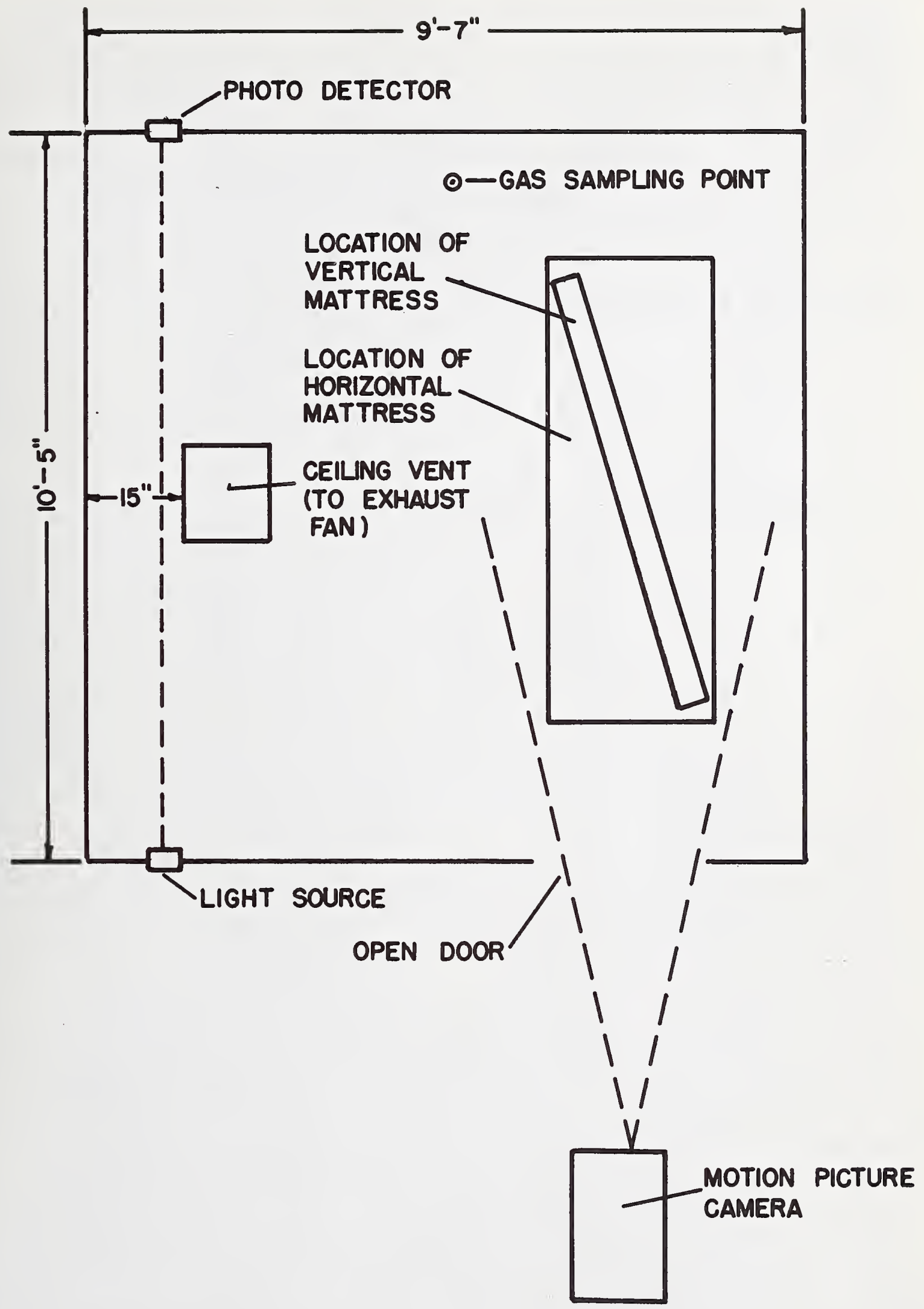

Figure 1. Plan View of Test Room 


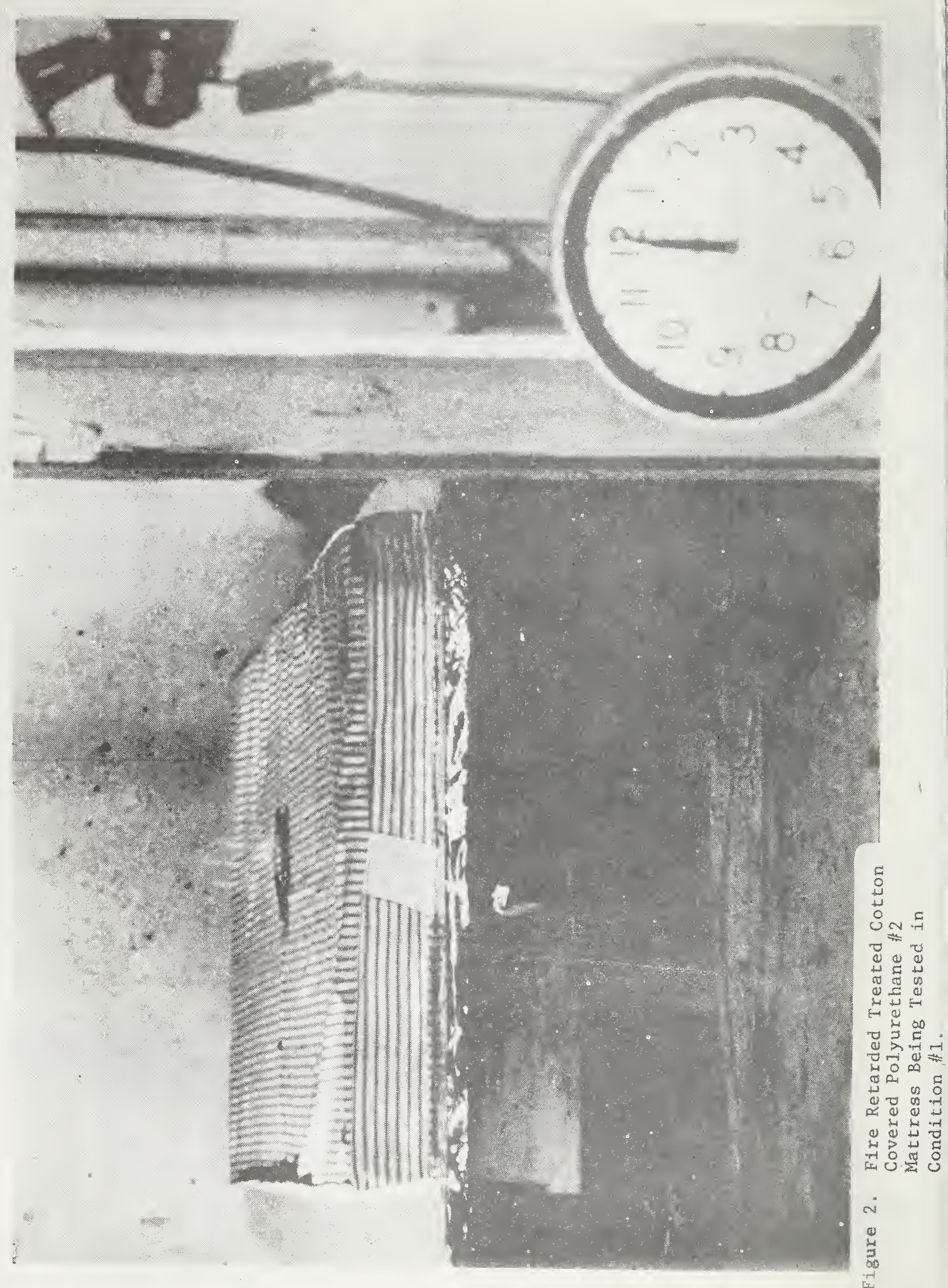




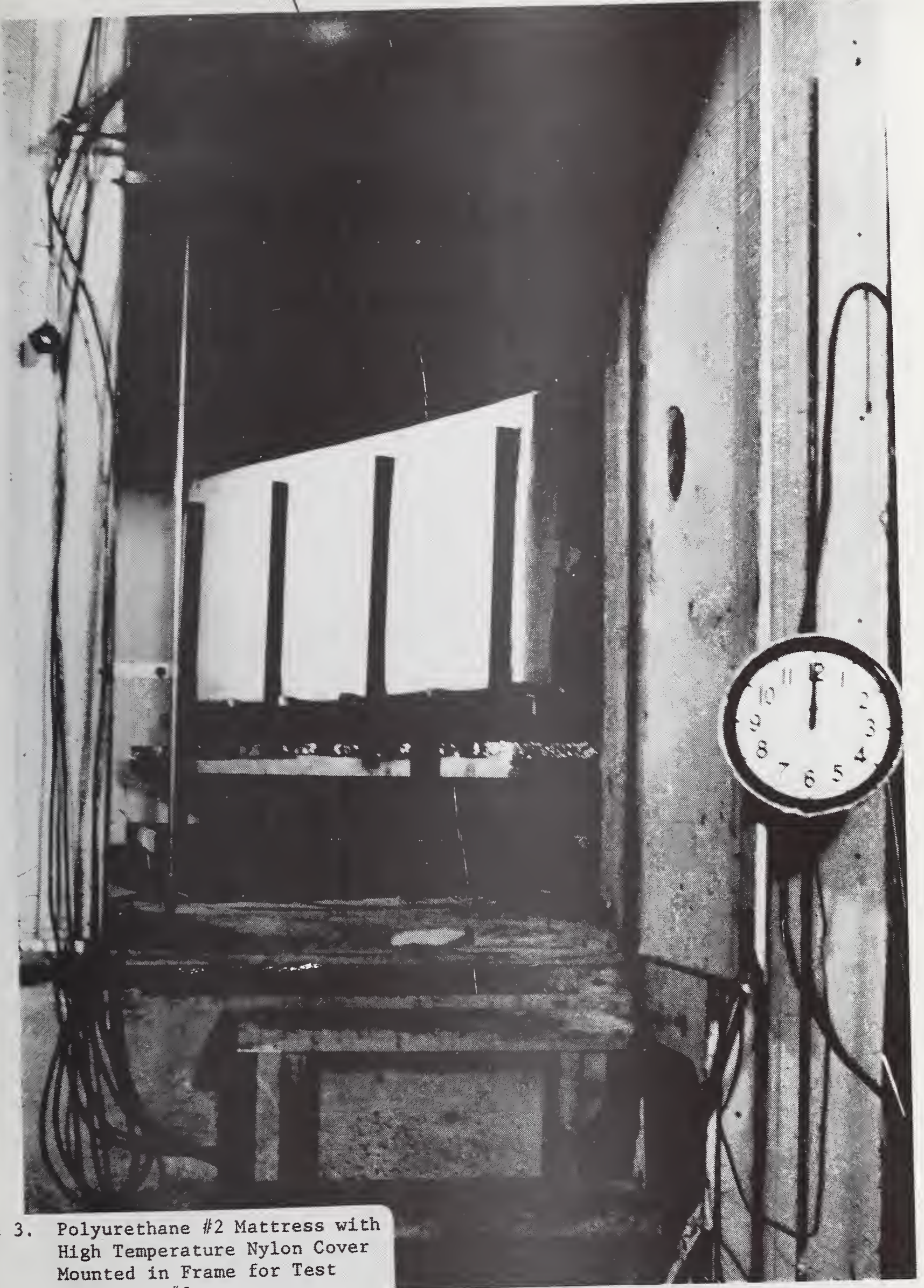

Figure 3. Polyurethane 非2 Mattress with High Temperature Nylon Cover Mounted in Frame for Test Condition 3 . 


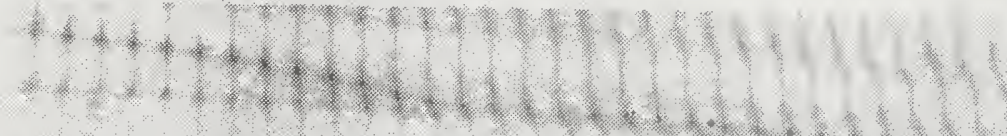




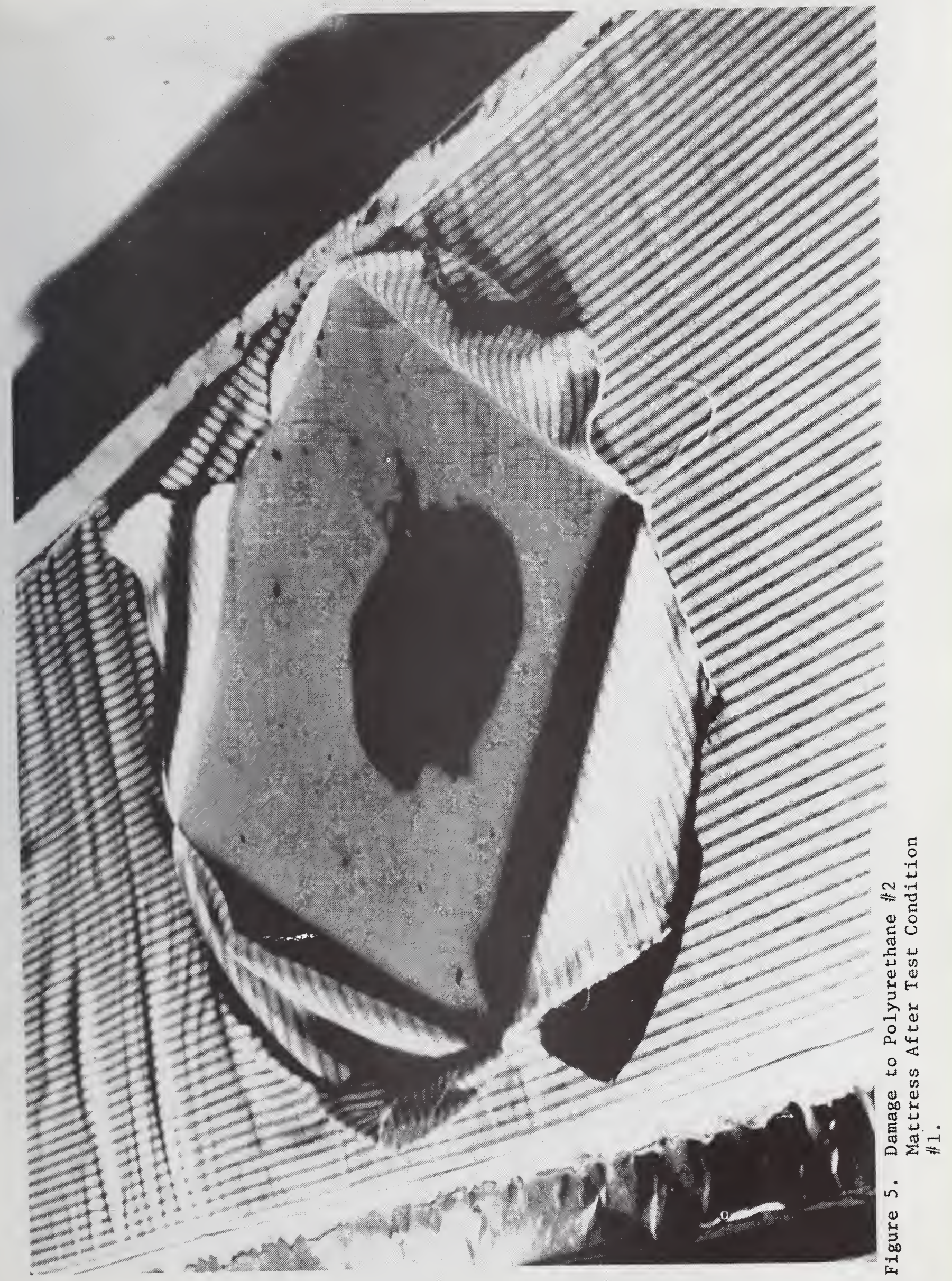




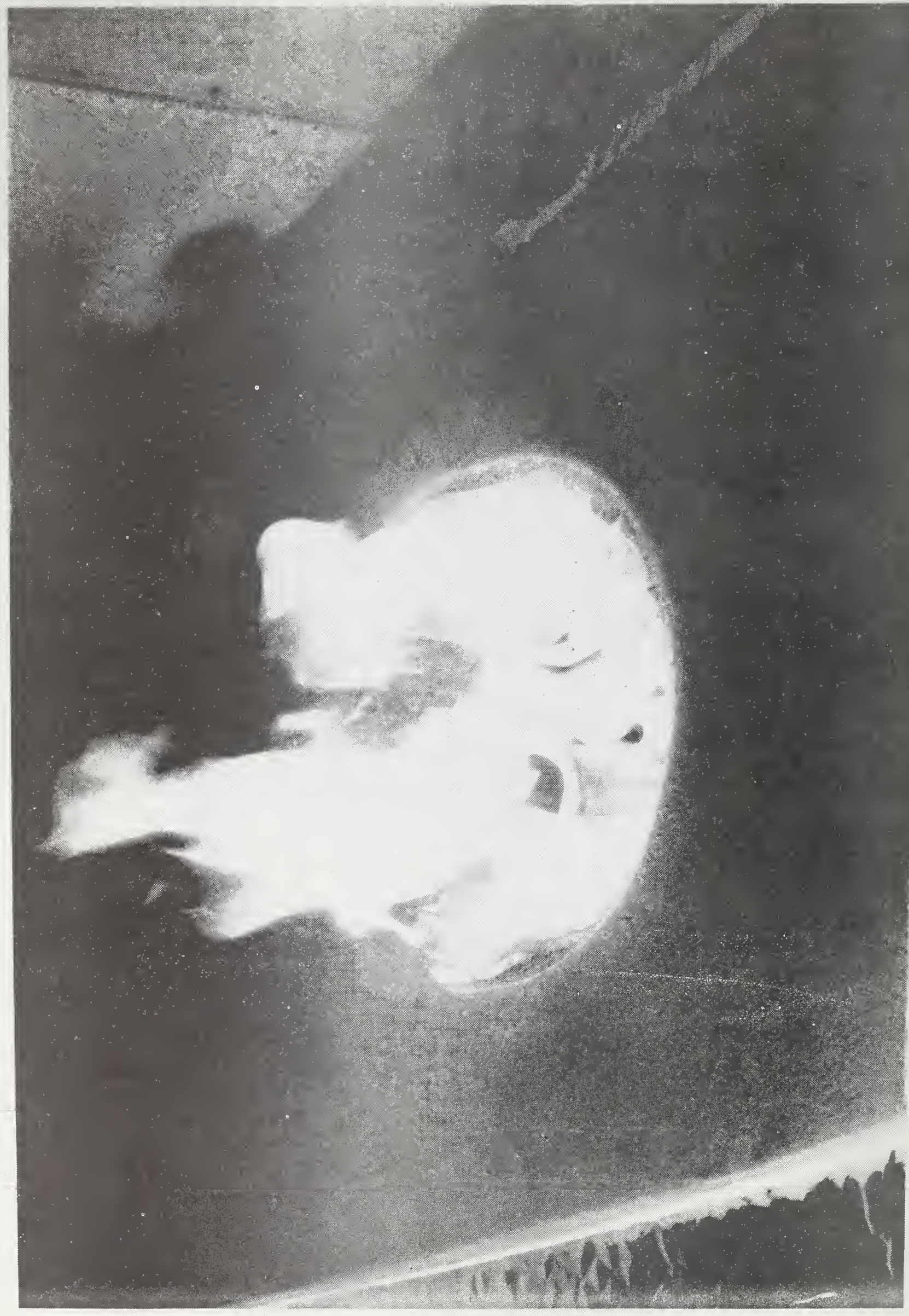

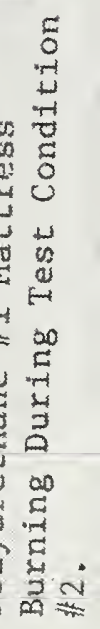



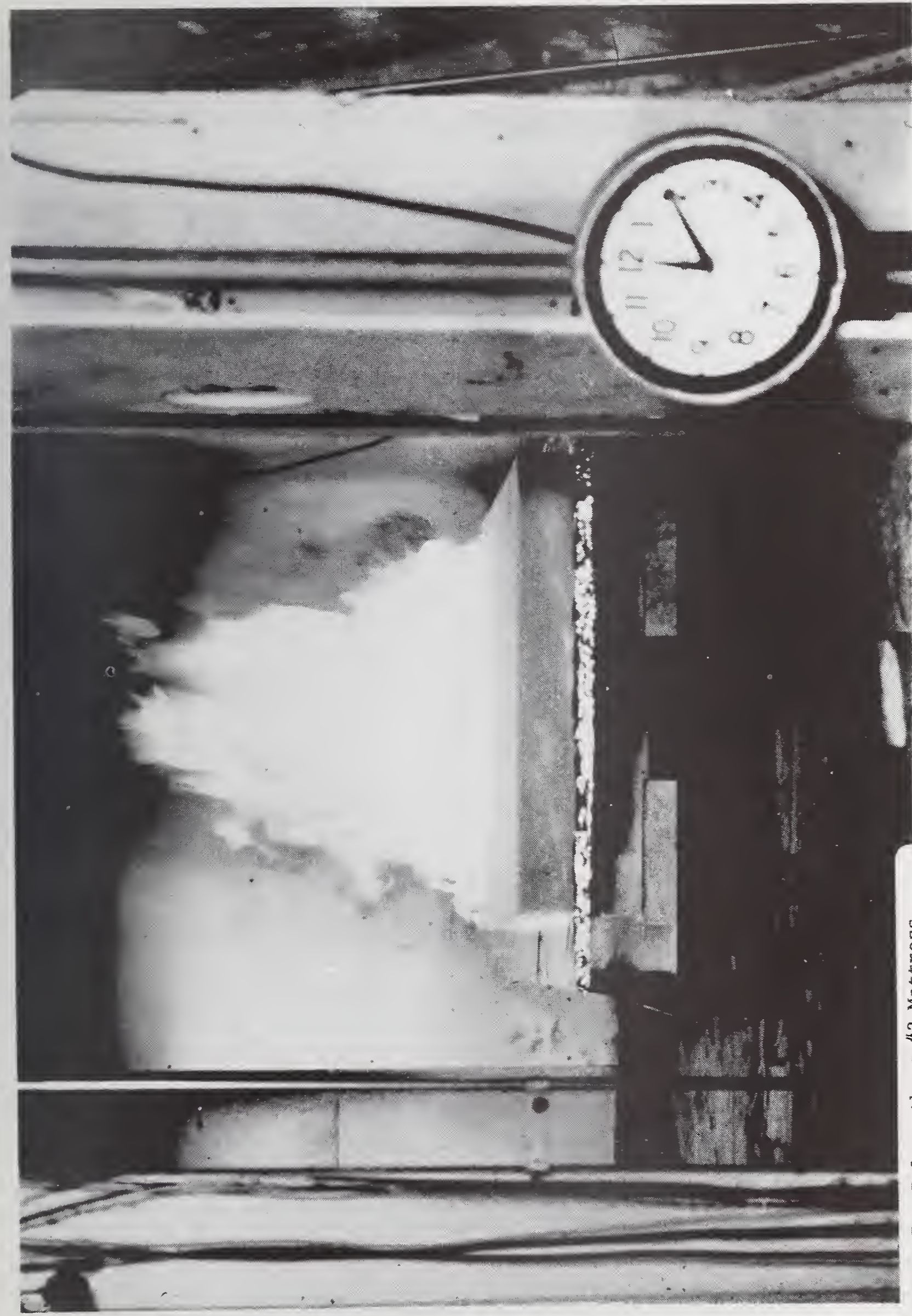

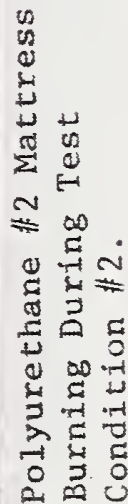




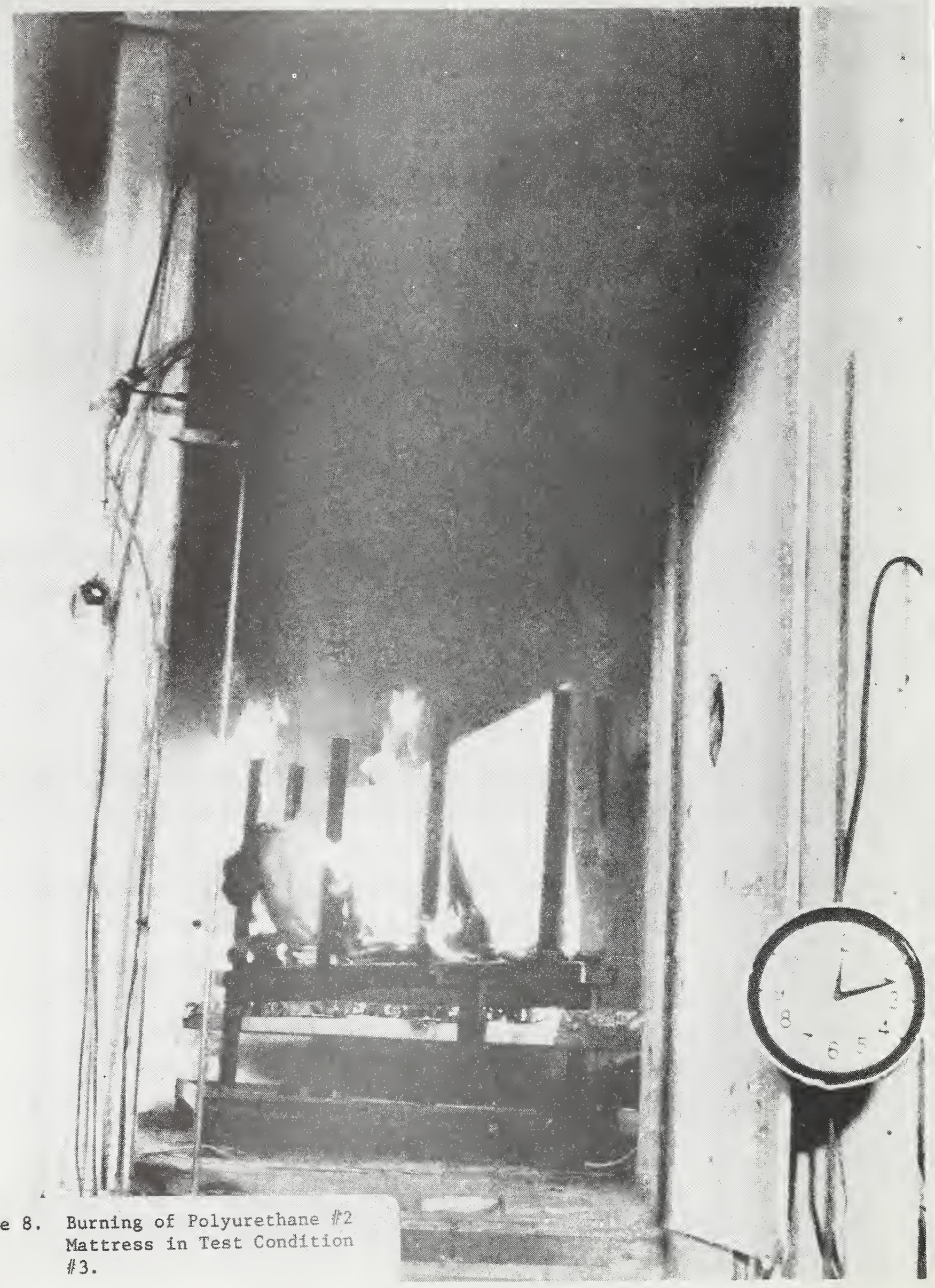




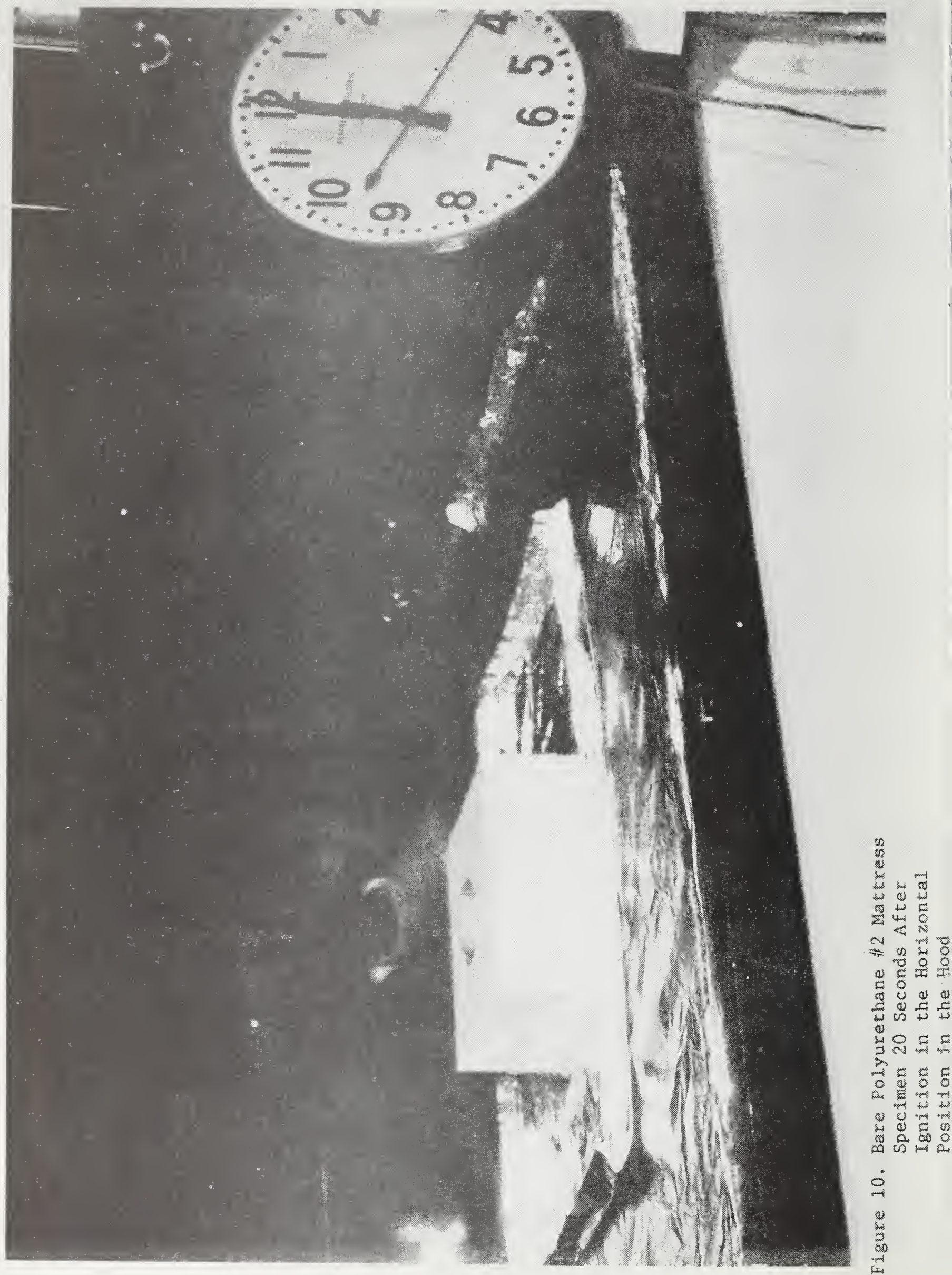




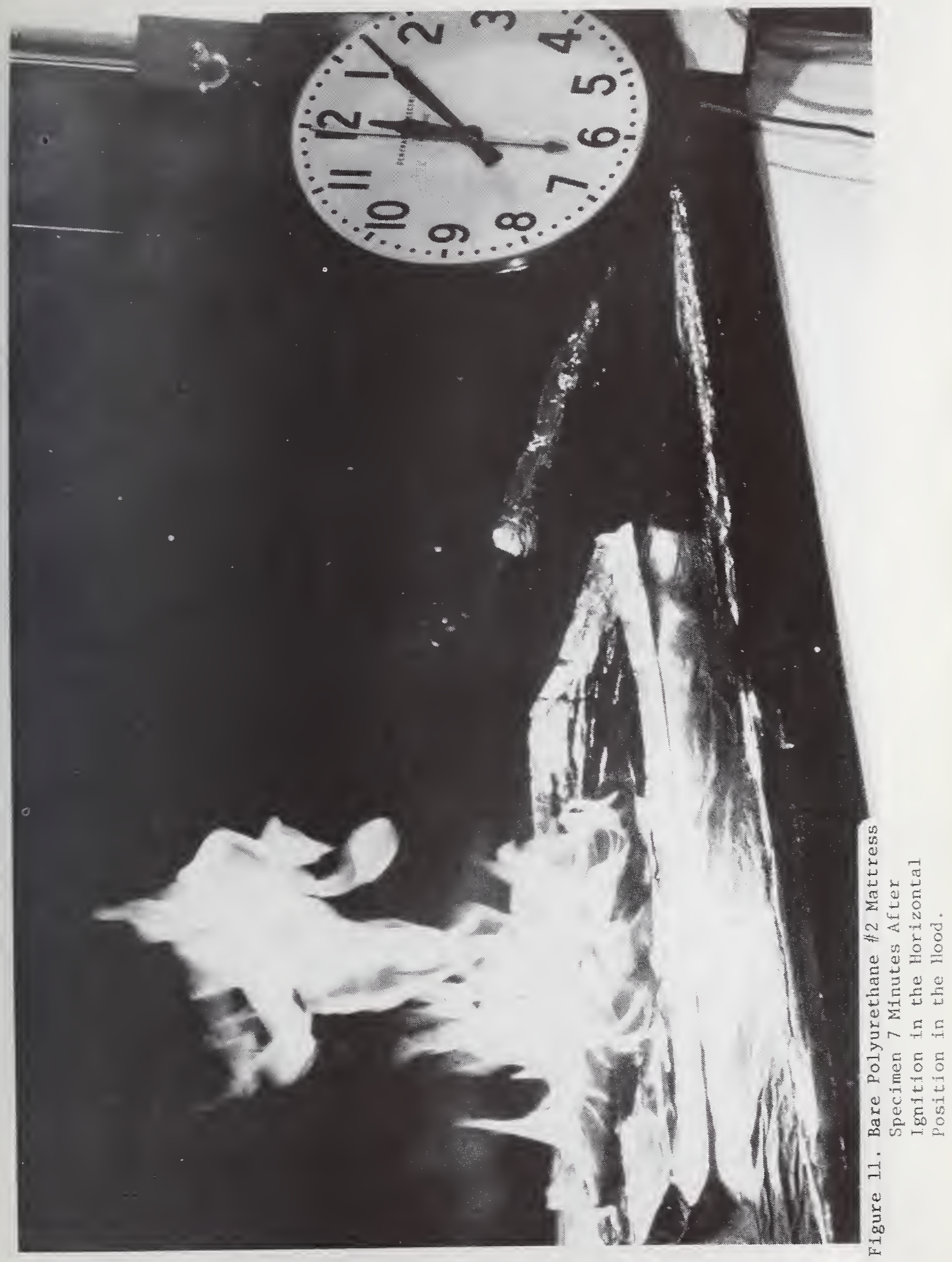




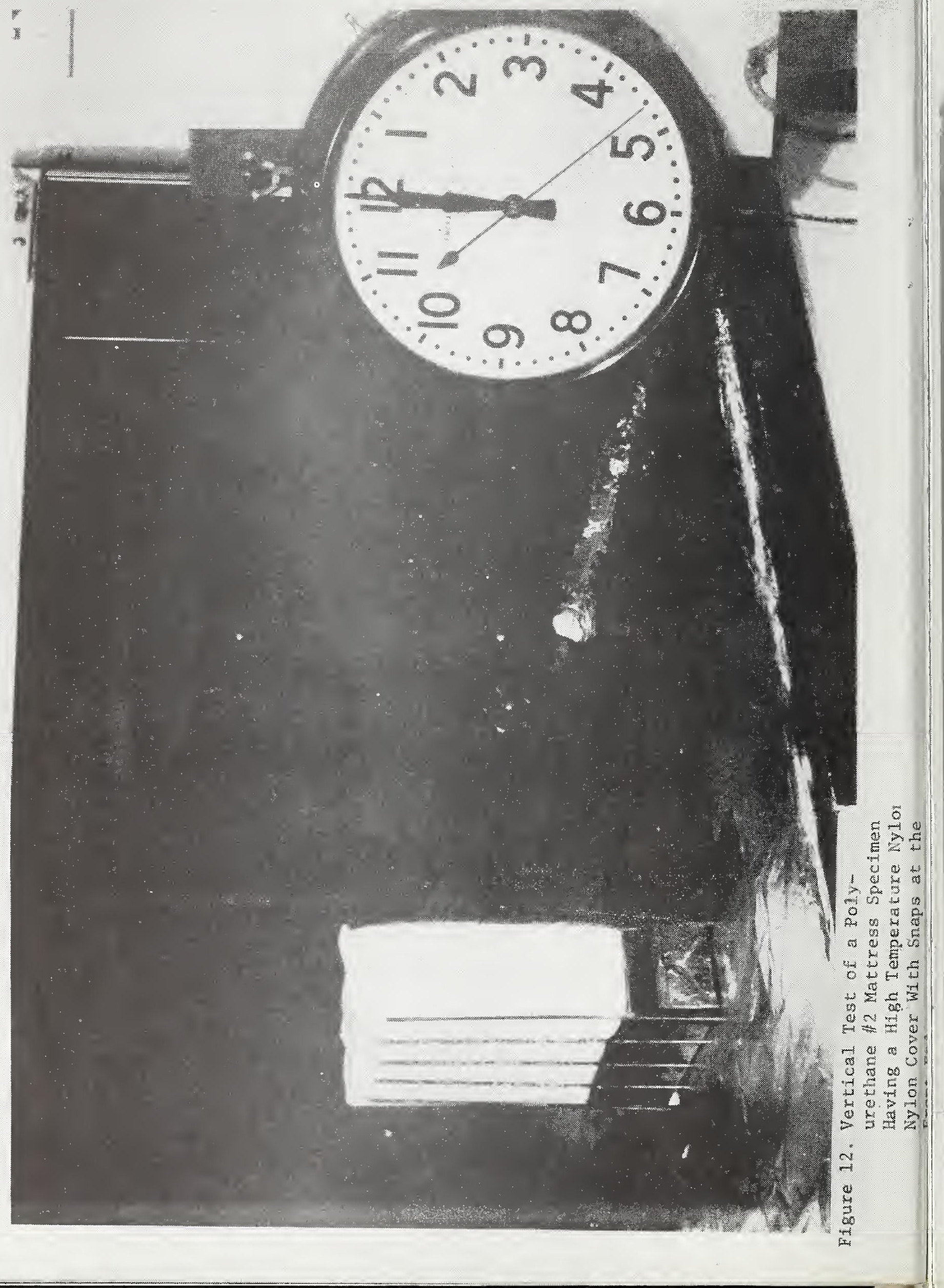




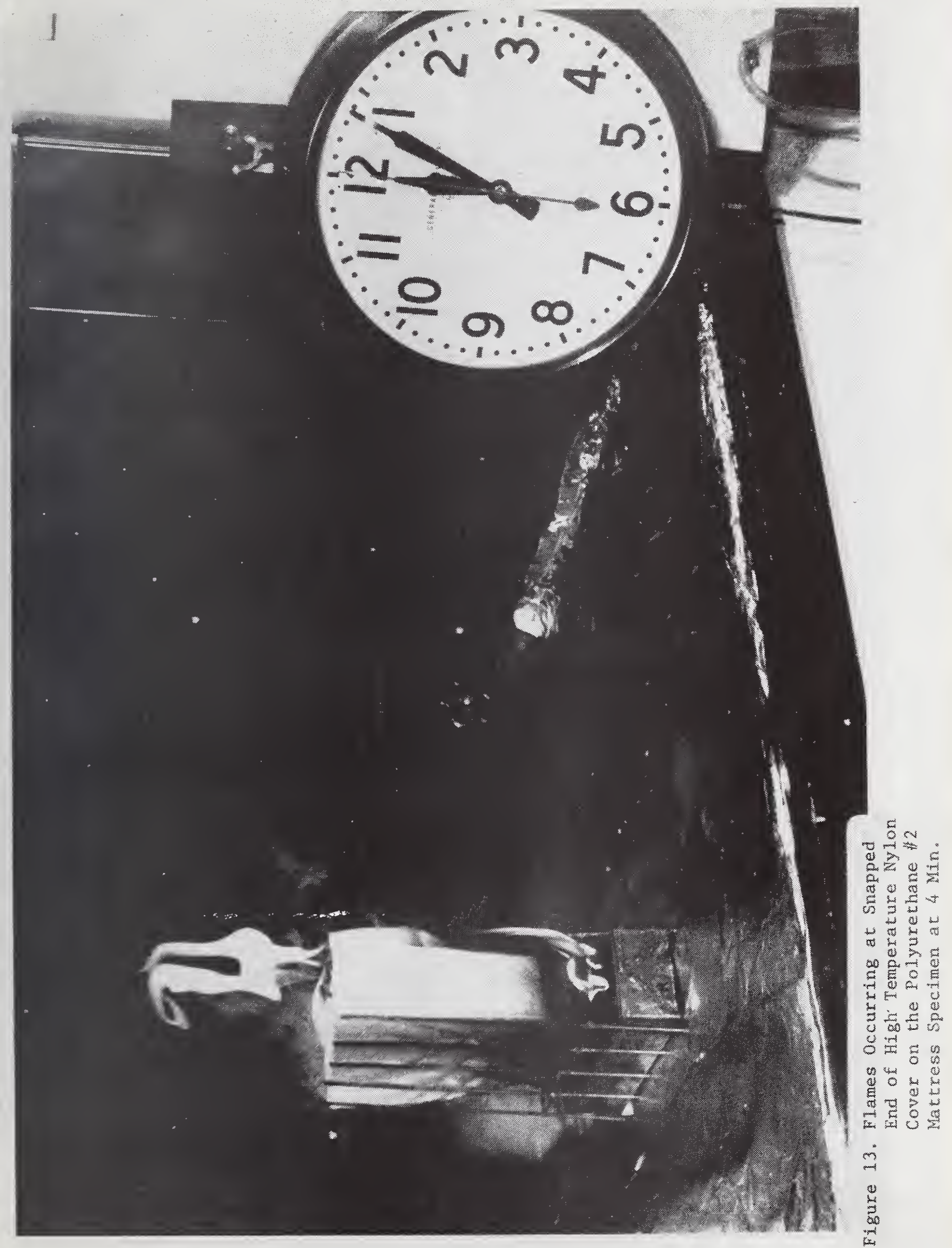




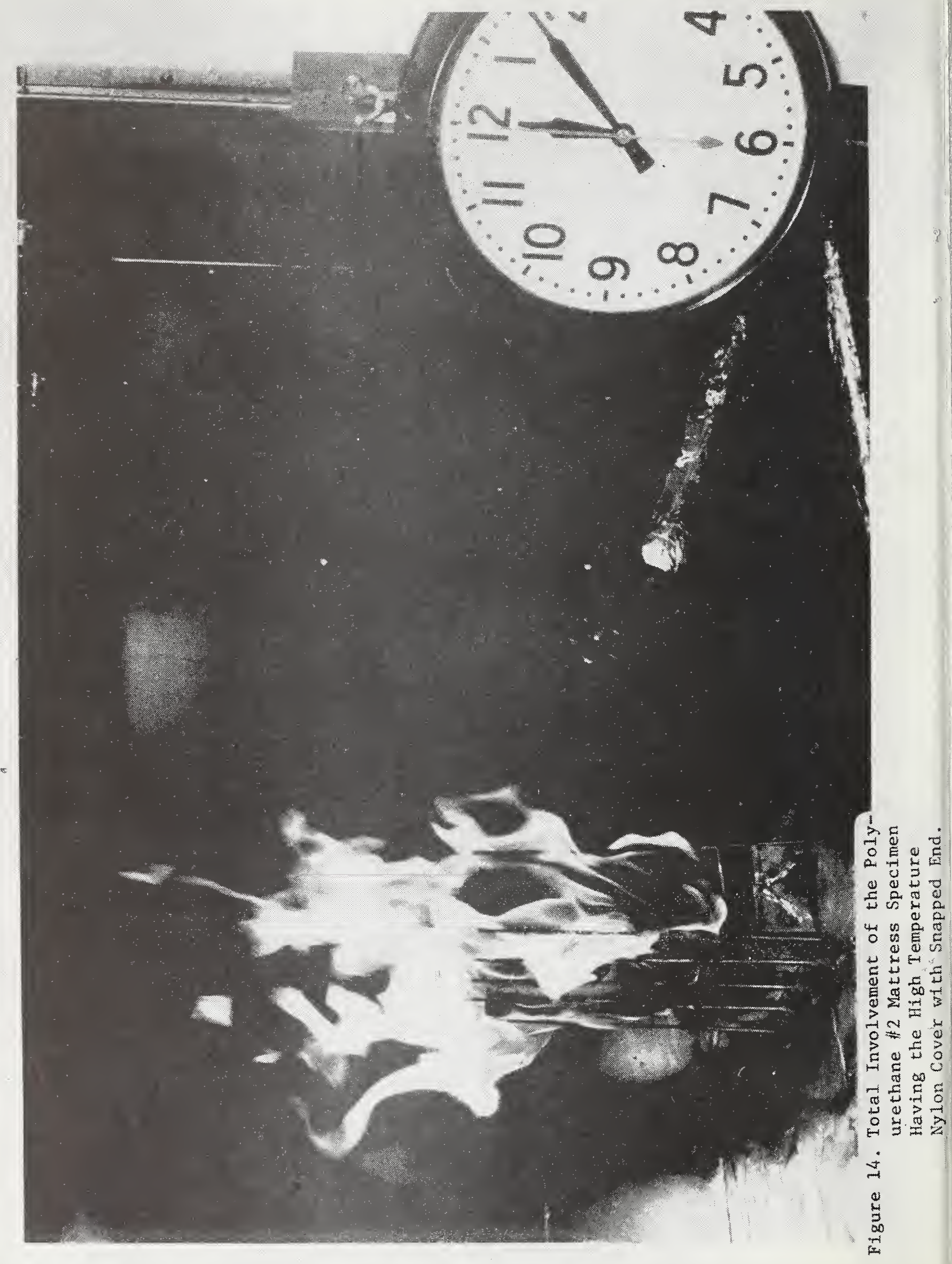


FORM NBS.114A $(1.71)$

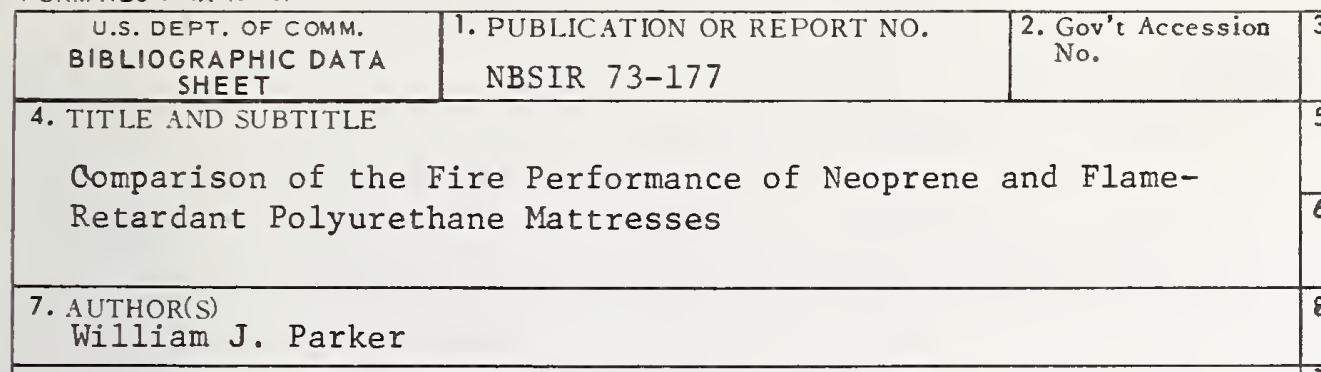

9. PERF ORMING ORGANIZATION NAME AND ADDRESS

NATIONAL BUREAU OF STAND ARDS

DEPAR TMENT OF COMMERCE

WASHINGTON, D.C. 20234

5. Publication Date

6. Performing Organization Code

8. Performing Organization NBSIR 73-177

10. Project/Task/Work Unit No.

\section{3}

11. Contract/Grant No.

MIPR NO. 72-6131F

12. Sponsoring Organization Name and Address

13. Type of Report \& Period Covered

Nava1 Ship Engineering Center

Hyattsville, Maryland 20782

Final -- 1972

14. Sponsoring Agency Code

15. SUPPLEMENTARY NOTES

16. ABSTRACT (A 200-word or less factual summary of most significant information. If document includes a significant bibliography or literature survey, mention it here.)

Ful1 scale fire tests of a neoprene and two different types of flame-retardant polyurethane mattresses were performed in a room sized compartment at the National Bureau of Standards. The mattresses were tested in two orientations, horizontal and vertical and with two types of coverings, a fire retardant treated cotton and a high temperature nylon ticking, in addition to the bare mattress insert. In addition to the visual observations, the burning rates, ceiling temperatures, optical density of the smoke, and the toxic gas concentrations were measured. This series of tests were repeated on small mattress sections to examine the relevance of small scale tests as a means of predicting full scale behavior. The flame spread index was measured with the radiant panel (ASTM E162); and the smoke and toxic gas concentrations were measured in the NBS smoke density chamber. Measurements were also performed in the heat release rate calorimeter and the ease of ignition test apparatus.

17. KEY WORDS (Alphabetical order, separated by semicolons)

Fire retardant; fire test; heat release ignition; mattress; smoke; toxic gases.

18. AVAILABILITY STATEMENT

UNLIMIT ED.

FOR OFFICIAL DISTRIBUTION. DO NOT RELEASE TO NTIS.

\begin{tabular}{|l|l|}
\hline $\begin{array}{l}\text { 19. SECURITY CLASS } \\
\text { (THIS REPORT) }\end{array}$ & 21. NO. OF PAGES \\
UNCL ASSIFIED & 22. Price \\
\hline $\begin{array}{l}\text { 20. SECUR ITY CLASS } \\
\text { (THIS PAGE) }\end{array}$ & \\
UNCL ASSIFIED &
\end{tabular}




